\title{
QUICKSERV: a service quality assessment tool for the quick-service restaurant industry
}

QUICKSERV:a service quality assessment tool

\author{
Mario Mendocilla and Paloma Miravitlles \\ Universitat de Barcelona, Barcelona, Spain, and \\ Jorge Matute \\ IQS School of Management, Universitat Ramon Llull, Barcelona, Spain
}

\begin{abstract}
Purpose - The purpose of this study is to empirically develop and validate a practical, consistent and specific scale to assess perceived service quality at the service encounter at quick-service restaurants (QSRs).

Design/methodology/approach - Development and validation of the scale involved a five-stage process. Data were collected from 430 customers of a QSR belonging to an international brand located in Barcelona. Surveys were applied immediately after the service encounter, using the face-to-face method. The scale development procedure involved exploratory and confirmatory factor analyses.

Findings - The results suggest a specific and parsimonious measurement scale, whose structure comprises 14 items in four dimensions. In contrast to previous studies, this study identified the appropriateness of splitting the interaction quality dimension into two single dimensions, one focusing on the interaction time and other on staff-customer interaction. Furthermore, these indicate that a speedy service, pleasant treatment and food quality are the most valued attributes in QSR.

Practical implications - This scale is a useful instrument to administer and assure service quality standards within QSR management systems. Its practical approach and short survey length ease data collection, considering that customers spend short amounts of time in this type of restaurant. Furthermore, it could also be used by franchisors and restaurant operators as a tool to monitor continuing compliance with service quality standards. Originality/value - The resulting scale introduces a novel four-factor structure with high goodness of fit to effectively measure customers' perceived service quality in QSRs, where the ease of use and speed of gathering client responses are a key factor for successful implementation.
\end{abstract}

Keywords Quick-service restaurants, Service quality, Scale development, Fast food, Franchising

Paper type Research paper

\section{Introduction}

When consumers grab a coffee or a hamburger at an international quick-service restaurant (QSR) chain in any country around the world, they always expect to receive the same standard of service quality. In fact, compliance with these expected quality standards is precisely one of the key factors for the development and growth prospects of QSR franchise chains (Cao and Kim, 2015; Krueger, 2013; Ottenbacher and Harrington, 2009). The QSR industry has achieved enormous growth in the last 10 years (Nguyen et al., 2018), and according to Mathe-Soulek et al. (2015), almost a third of total restaurant sales correspond to QSR, making it a highly competitive industry. In this context, the annual survey conducted by the NPD Group shows that consumer spending in QSR reached almost three hundred billion US dollars in 2018 in the US market alone (Lock, 2019). Indeed, DiPietro et al. (2013) and Swimberghe and Wooldridge (2014) have highlighted the growth of this industry as a good enough reason in itself to research the field.

(C) Mario Mendocilla, Paloma Miravitlles and Jorge Matute. Published by Emerald Publishing Limited. This article is published under the Creative Commons Attribution (CC BY 4.0) licence. Anyone may reproduce, distribute, translate and create derivative works of this article (for both commercial and noncommercial purposes), subject to full attribution to the original publication and authors. The full terms of this licence may be seen at http://creativecommons.org/licences/by/4.0/legalcode

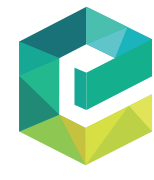

British Food Journal Vol. 123 No. 13,2021 pp. $241-259$ Emerald Publishing Limited DOI 10.1108/BFJ-12-2020-1108 
BFJ

123,13

Some of the most successful globally expanded fast-food chains, such as McDonald's, Pizza Hut, Subway and KFC, are part of the QSR industry, a sector whose growth over the years has been made possible by the constant addition of new franchises and the opening of new restaurants around the world (Ottenbacher and Harrington, 2009). In this global context, the rapid expansion of this industry has not only generated intense competition between the different QSR chains, but also between restaurants in the same chain (Cao and Kim, 2015). It is widely known that QSR chains mainly operate under franchise systems (Krueger, 2013), and each of these have their own set of service quality standards that must be assumed and internalized by all of their restaurants in order to thrive in competitive environments (Tsai et al., 2007). In that sense, franchisors need tools to monitor the continuous fulfillment of the standards established under contractual obligations (Hoover et al, 2003) to ensure the initially intended level of service quality.

An additional particularity of the QSR industry is that individuals consume the service at virtually the same time that it is produced, making the service encounter a key component of service management (Gummesson, 2014). So perceived quality is not only about coffee or hamburgers tasting the same in any restaurant around the world, but is also about it being served the same way regardless of geographic location. In this regard, compliance with the established service quality standards during the service encounter is a fundamental factor to attract and retain consumers (Tsai et al., 2007). Likewise, the literature on product quality and customer satisfaction confirms that service quality drives consumer gratification and highlights its practical significance linked to strategic management (Cronin et al., 2000).

Despite the importance of service quality in the success and growth of QSR chains, several researchers (Namkung and Jang, 2008; Ryu and Jang, 2008; Antun et al., 2010) have highlighted that existing service quality assessment scales are not inclusive enough to adequately capture the real customer experience in QSR. In the same vein, Wu and Mohi (2015) stated that extant scales do not fully capture the service quality construct in QSR because they focus more on interaction and the physical environment than on the main outcome, which primarily comprises food quality aspects. In this regard, existing measurement options present limitations that make them unsuitable for the QSR context. For example, one of the most common scales used in different service industries, SERVQUAL (Parasuraman et al., 1988), is too generalist and does not take into account the food quality dimension, which is one of the most influential factors in the restaurant industry (Bufquin et al., 2017) and the main tangible aspect that affects the whole restaurant experience (Ryu and Lee, 2017). Moreover, DINESERV (Stevens et al., 1995) was the first specific scale for the restaurant industry, but it does not include food quality either. TANGSERV (Raajpoot, 2002) is focused on the measurement of tangible aspects, rather than interaction quality (i.e. it does not include all service quality facets), while DINESCAPE (Ryu and Jang, 2008) only assesses the physical environment in upscale restaurants and again fails to take into account the food quality dimension. Furthermore, the hierarchical scale developed by Wu and Mohi (2015) was the first model to be specifically developed for fast-food restaurants, but its complex structure composed of 46 items hampers its practical and continuous application to restaurant management systems. Other recent proposals (Oh et al., 2019; Slack et al., 2020) have employed three-dimensional structures to assess service quality in the context of QSR. These studies included the quality of the food, physical environment and employee service rather than the interaction quality dimension suggested by Wu and Mohi (2015). These scales therefore consider employees to be the only factor responsible for the speed of service and interaction quality, leaving out the roles of internal process management and organizational capacity. This omission is significant since there is a clear relationship between managerial decisions and the overall operational efficiency of their restaurants (Kukanja and Planinc, 2020), because employee performance ultimately depends on the successful management and coordination of each restaurant.

All these extant scales are either inaccurate and incomplete or, on the contrary, too long to be easily implemented in QSR management systems, so an updated scale that covers main 
aspects of service quality in QSR context is needed. Consequently, in order to overcome the aforesaid limitations, the objective of this study is to develop a specific service quality scale for the QSR industry, with a practical focus and based on a second-order structure, hereinafter called QUICKSERV. This research builds on and extends the service quality theory by developing a new scale that is particularly adapted to the QSR context following a rigorous five-step procedure and verified through the analysis of 430 customer responses that were collected at a QSR located in Barcelona.

The contributions of this study are fourfold. First, this scale provides empirical support QUICKSERV:a service quality assessment tool for Rust and Oliver's (1994) conceptualization of service quality. Second, it is a consistent and parsimonious scale composed of 14 items in four dimensions with satisfactory goodness-of-fit indices that can be used in further research on the QSR industry. Third, the new scale represents a practical and accurate tool that takes a short time to answer and could easily be included in QSR management systems to gather real-time customer data on a continuing basis, supporting the operational management of each restaurant. As a fourth contribution, the resulting scale can be used as a control instrument to assure service quality standards in international franchise management, because when firms expand internationally their organizations become more complex, leading to some loss of control over their operations and products (Rosado-Serrano et al., 2018). Accordingly, QUICKSERV could be used as a noncoercive control tool, since this control mechanism predominantly acts as a support function in franchise relationships (Doherty, 2007).

This research paper is structured as follows. First, it presents the research context and shortcomings in this introduction. It then reviews the literature on service quality assessment. This is followed by the methodology section, where the scale development and data collection processes are explained. It then verifies the latent structure and presents the results and ends by discussing the findings and managerial implications, in order to draw the main conclusions.

\section{Literature review}

\subsection{Service quality benefits}

Decades ago, quality was considered a competitive advantage per se, but nowadays it merely denotes a necessary condition to obtain market acceptance. In fact, several previous studies have demonstrated that quality, and more specifically service quality, has a positive effect on customer satisfaction and firm image. For example, Ryu and Han (2010) have identified among customers of three quick-casual restaurants in a Midwestern state in the USA that service quality affects customer satisfaction. Nam et al. (2011) found a positive influence of service quality on customer satisfaction and brand loyalty in hotel and restaurant customers in the United Kingdom. In the same vein, Bujisic et al. (2014) and Richardson et al. (2019) observed a positive influence of service quality on overall satisfaction and future intentions among QSR customers. Finally, Qin and Prybutok (2008) asserted that service quality assessment provides decisive information to improve business performance and strategic positioning in the marketplace.

Despite the proven positive effects of service quality on customer satisfaction, the benefits of implementing quality standard systems are difficult to quantify and many organizations do not allocate sufficient resources to their measurement (Djofack and Camacho, 2017). Service quality is difficult to assess because it is not only based on a delivered product, but also on the service itself. Previous studies such as the one by Angelova and Zekiri (2011) have argued that part of the difficulty with assessing service quality is that it cannot be measured by strictly objective indicators, unlike product quality. In addition, traditional methods to assess service quality are inappropriate for today's competitive markets, which have incorporated new technologies and social networks in their business management, making it necessary to develop new instruments with new approaches that take into consideration the whole customer experience (Calabrese and Scoglio, 2012). Despite the difficulties of 
BFJ 123,13

\section{4}

measuring service quality, since 1988 there have been several attempts to develop scales to do so (see Table 1).

Of the different theories and conceptual frameworks to approach quality service assessment (Nguyen et al., 2018), this research is based on Rust and Oliver's (1994) conceptualization of service quality and the means-end theory (Reynolds and Olson, 2001). The former proposes a three-component model, based on three elements that are always present in service industries: product, environment and delivery. This approach was adopted by Brady and Cronin (2001) to develop a hierarchical structure that captures the perception of service quality in different service industries. Second, the means-end theory, which explains the relevance of the connection between motivational product attributes and consumer decision-making (Reynolds and Olson, 2001), pinpoints that the customer's knowledge of service quality attributes drives purchasing behavior, supporting the importance of measuring the perception of service quality (Paul et al., 2009). Hence, Rust and Oliver (1994) provide a conceptual framework, as a starting point for our study, and Reynolds and Olson (2001) support the importance of the perception of service quality on consumer behavior.

\subsection{Service quality assessment scales in the QSR industry}

A QSR is a type of restaurant that uses a limited but quick service to offer a small menu at relatively low prices, what is also known as a fast-food restaurant. Lu and Chi (2018) define these as "fast food establishments where customers receive quick meals with minimal table

\begin{tabular}{|c|c|c|c|c|}
\hline $\begin{array}{l}\text { Scale (Authors and } \\
\text { year) }\end{array}$ & Domains & Dimensions & Items & Industry context \\
\hline $\begin{array}{l}\text { SERVQUAL } \\
\text { (Parasuraman et al., } \\
\text { 1988) }\end{array}$ & 5 & $\begin{array}{l}\text { Tangibles, reliability, } \\
\text { responsiveness, assurance, } \\
\text { empathy }\end{array}$ & 22 & General service industries \\
\hline $\begin{array}{l}\text { LODGSERV } \\
\text { (Knutson et al., 1990) }\end{array}$ & 5 & $\begin{array}{l}\text { Tangibles, reliability, } \\
\text { responsiveness, assurance, } \\
\text { empathy }\end{array}$ & 26 & Hospitality industry \\
\hline $\begin{array}{l}\text { SERVPERF (Cronin } \\
\text { and Taylor, 1992) }\end{array}$ & 5 & $\begin{array}{l}\text { Tangibles, reliability, } \\
\text { responsiveness, assurance, } \\
\text { empathy }\end{array}$ & 22 & General service industries \\
\hline $\begin{array}{l}\text { DINESERV (Stevens } \\
\text { et al., 1995) }\end{array}$ & 5 & $\begin{array}{l}\text { Tangibles, reliability, } \\
\text { responsiveness, assurance, } \\
\text { empathy }\end{array}$ & 29 & Restaurants \\
\hline $\begin{array}{l}3 \mathrm{D}^{[1]}(\text { Brady and } \\
\text { Cronin, 2001) }\end{array}$ & 3 & $\begin{array}{l}\text { Interaction quality, physical } \\
\text { environment quality, outcome } \\
\text { quality }\end{array}$ & 35 & Different service industries \\
\hline $\begin{array}{l}\text { TANGSERV } \\
\text { (Raajpoot, 2002) }\end{array}$ & 3 & $\begin{array}{l}\text { Layout/design, product/service, } \\
\text { ambiance/social }\end{array}$ & 13 & $\begin{array}{l}\text { Foodservice industry } \\
\text { (focused on tangible } \\
\text { elements) }\end{array}$ \\
\hline $\begin{array}{l}\text { DINESCAPE (Ryu } \\
\text { and Jang, 2008) }\end{array}$ & 6 & $\begin{array}{l}\text { Facility aesthetics, ambience, } \\
\text { lighting, table settings, layout, } \\
\text { service staff }\end{array}$ & 21 & $\begin{array}{l}\text { Upscale restaurants } \\
\text { (focused on physical } \\
\text { environment elements) }\end{array}$ \\
\hline $\begin{array}{l}\text { DinEX (Antun et al., } \\
\text { 2010) }\end{array}$ & 5 & $\begin{array}{l}\text { Food, service, atmosphere, } \\
\text { social, health }\end{array}$ & 20 & $\begin{array}{l}\text { Foodservice industry } \\
\text { (scarcely used in further } \\
\text { studies) }\end{array}$ \\
\hline $\begin{array}{l}\text { Hierarchical (Wu and } \\
\text { Mohi, 2015) }\end{array}$ & 3 & $\begin{array}{l}\text { Outcome quality, interaction } \\
\text { quality, physical environment } \\
\text { quality }\end{array}$ & 46 & Fast-food restaurants \\
\hline
\end{tabular}

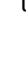

Table 1.

Service quality scales 
service” (p. 2832). Most QSR chains work with centrally supplied kitchenettes, whereby ingredients are prepared or precooked on a large scale to facilitate faster operations at each individual restaurant (Ottenbacher and Harrington, 2009). QSR chains provide low price products and services under stringent quality standards. Ensuring compliance with these standards helps to boost customer satisfaction and loyalty, which are crucial for increasing revenue and profits (Qin and Prybutok, 2008). In the restaurant industry, it is important not only to understand how consumers evaluate the service in a general manner, but also to identify the basic dimensions that make up this overall experience (Wu and Mohi, 2015). Furthermore, restaurant managers need to find new ways to stand out from the competition and to retain their customers by providing superior performance (Cao and Kim, 2015).

SERVQUAL is a commonly used scale to measure service quality, but it has been criticized due to the universal approach of its application, since it does not consider the idiosyncrasies and customer perceptions of each industry (Markovic et al., 2010). With the same generic focus, Brady and Cronin (2001) developed a scale composed of 27 items in nine subdimensions and three dimensions to measure service quality from a hierarchical approach. It was tested in four different service industries, without focusing on any of them specifically. Despite being widely accepted, its general scope means its use has not been generalized in subsequent studies.

A few scales have been developed directly in relation to the restaurant industry. First, DINESERV was adapted from SERVQUAL and comprises 29 items, which were tested on three types of restaurant. Another is DINESCAPE, which was developed to measure perceptions of the physical environment and tangible elements in upscale restaurants, but without considering external physical elements. Neither scale includes food quality as a service quality dimension, which is an important weakness because food quality is a key factor for restaurant success (DiPietro, 2017). Unlike these two previous scales, TANGSERV was developed to measure only tangible aspects in the foodservice industry and thus includes items for evaluating food-related matters. However, this scale does not consider such a relevant intangible aspect as staff-customer interaction, which is a significant factor for achieving customer satisfaction (Ryu and Han, 2010). Another proposed scale for the restaurant industry is DinEX (Antun et al., 2010), which comprises 20 items in five dimensions, including two new dimensions related to social and health aspects. This scale was recently used by Bufquin et al. (2017) in a casual Italian restaurant to measure the influence of service quality on customer satisfaction, and they identified that three of its five dimensions (service, atmosphere and social) were not statistically supported. In addition, the health dimension comprises only two items related to the healthfulness of the food; so it may not be appropriate for all kinds of QSR.

The hierarchical scale developed by $\mathrm{Wu}$ and Mohi (2015) is specific to fast-food restaurants and is composed of three dimensions, ten subdimensions and a total of 46 items. The extensiveness of this scale implies a major challenge for implementation in restaurant management systems and most particularly in QSR restaurants, where customers tend to spend little time. Furthermore, the range of this hierarchical scale does not facilitate its usefulness in future studies that analyze more complex structural models.

Finally, recent studies on QSR restaurants, such as Oh et al. (2019) and Slack et al. (2020), did not develop specific service quality scales, although they did assess three dimensions of service quality within more complex structural models. These studies considered the employee service quality dimension rather than the interaction quality dimension, as recommended by Rust and Oliver (1994). Consequently, given the features of existing scales and the particularities of this industry, there is a clear need for a practical and consistent assessment scale that continuously provides customer data and monitors compliance with the service quality standards of all owned and franchised business units. 
BFJ

123,13

246

\section{Research methodology}

\subsection{Scale development}

The development of QUICKSERV follows the five-step procedure suggested by Churchill (1979), using a similar process to that used to develop previous scales (Ryu and Jang, 2008; Antun et al., 2010; Wu and Mohi, 2015).

3.1.1 First step: domain of constructs. The first step involved specifying the domains of the main constructs, which required an extensive initial review of service quality scales and the literature on operations management at QSR. As a result, three key components for assessing service quality were identified in the restaurant industry: the physical environment, food quality and personal attention (Ryu and Han, 2010; Bujisic et al., 2014). Hence, following a multidimensional approach, this study initially proposed these three domains as suggested by Brady and Cronin (2001) and Wu and Mohi (2015), but considering new denominations, adapted to the QSR context, such as physical environment perception, interaction quality perception and food quality perception.

3.1.2 Second step: initial pool of items and initial content assessment. From this literature review, we generated a list of 25 items that were distributed among the three initially proposed domains. In order to guarantee the validity of the content of the items for the QSR context, experts were specifically required to evaluate the degree of appropriateness of each and to opine on how these items were especially suitable or applicable in the QSR context. Following Hinkin (1995), these preliminary items were evaluated on the basis of the extensive know-how of a group of 15 experts who have worked as general managers, directors of operations, area supervisors and store and shift managers at Dunkin, Burger King, McDonald's, KFC or Starbucks. These experts afforded their individual evaluations, answering an online survey in which they assessed the importance of each of the 25 items with regard to service quality and operations management in QSR. For more in-depth analysis of the items, and especially those related to operational management, and to establish the essential attributes in order for an assessment scale to be functional in the QSR setting, we also held qualitative interviews with seven of the 15 experts. Together, the online survey and interviews enabled us to identify the most relevant items, to reformulate some of these and to rule out irrelevant, ambiguous or redundant indicators.

After this first analysis, and using the expert's recommendations, the most significant modifications involved: dropping three items ("Nice background music," "Well-maintained equipment and utensils" and "Staff show a high command of the language of interaction"); merging two items into a single one ("Menu board easy to read and understand" and "Displays and promotional materials easy to read and understand", becoming item 6); and two items were substantially reworded, namely "Staff provide a motivating sales pitch" being reworded in item 17, and "Attractive place and pleasing interior design" being reworded in item 2. In short, from this round, the resulting scale was composed of 21 items. The first ten items corresponded to the perception of the physical environment, the next seven items to the perception of interaction quality and the last four items to the perception of food quality. Table 2 shows the list of the 21 initial statements.

3.1.3 Third step: content adequacy assessment. After the experts' initial evaluation, a pretest was conducted in order to check the respondents' comprehension of the items and confirm the content validity. The selected firm is a widely popular QSR brand that serves coffee, beverages, pastries and sandwiches all day and is one of the world's leading franchisors of QSRs. It has more than 21,000 points of sale in 60 countries, including many of the most-visited cities in the world. This choice allowed us to analyze an international restaurant management system and consequently broaden the impact of this study and the managerial implications for the QSR industry. For a whole week, we conducted 40 personal surveys on different customers at a QSR in a touristic area of Barcelona. These face-to-face 


\begin{tabular}{|c|c|c|}
\hline Item & Statements & QUICKSERV:a \\
\hline 1 & Comfortable seats and tables & assessment \\
\hline 2 & Attractive place and pleasant atmosphere & \\
\hline 3 & Well-painted walls and proper lighting & \\
\hline 4 & Attractive exterior signs and appearance & \\
\hline 5 & Comfortable indoor temperature & \\
\hline 6 & Menu board and promotional displays easy to read and understand & 247 \\
\hline 7 & Attractive product exhibition & \\
\hline 8 & Clean and well-maintained rest rooms & \\
\hline 9 & Functional and easily-accessed service bar & \\
\hline 10 & Clean and well-maintained restaurant & \\
\hline 11 & Proper service time (order preparation) & \\
\hline 12 & Enough staff to attend to consumers & \\
\hline 13 & Experienced and well-trained employees & \\
\hline 14 & Staff have a pleasant attitude & \\
\hline 15 & Staff have a clean and well-groomed look & \\
\hline 16 & Staff are dynamic and friendly & \\
\hline 17 & Staff offer upselling options & \\
\hline 18 & Fresh and properly cooked food & \\
\hline 19 & Delicious and tasty food & \\
\hline 20 & Sufficient variety of choices on the menu & Table 2. \\
\hline 21 & Practical and hygienic food packaging & Initial items \\
\hline
\end{tabular}

questionnaires yielded a general good understanding of the header question and of the 21 items included in the initial version of the scale. Additionally, we identified that less than $1 \mathrm{~min}$ was needed to introduce the survey and customers took an average of $4 \mathrm{~min}$ to answer all the questions.

3.1.4 Fourth step: questionnaire administration. The next step involved collecting data at the same QSR in Barcelona by administering questionnaires immediately after the service encounter. The questionnaire comprised 21 items and was answered on a seven-point Likert scale. Regarding sample size, Worthington and Whittaker (2006) suggested that at least 300 observations constitute a satisfactory sample size in most cases, while Fabrigar and Wegener (2012) argued that for communalities lower than 0.40, the minimum sample size is 400 observations. Therefore, based on these criteria, 430 personal face-to-face questionnaires were administered to customers of the QSR. These surveys were personally conducted by the researchers over four weeks in November 2019. The sample varied in gender $($ female $=53.3 \%$; male $=46.7 \%)$, age $(\leq 25$ years of age $=34.2 \% ; 26-40$ years of age $=43.5 \% ; 41-55$ years of age $=14.6 \% ; \geq 56$ years of age $=7.7 \%)$ and the bill for meal $(<€ 5.00=28.6 \% ; € 5.00-€ 10.00=42.3 \% ; € 10.01-€ 15.00=20.2 \%$; $€ 15.01-$ $€ 20.00=6.3 \% ;>€ 20.00=2.6 \%$ ).

3.1.5 Fifth step: scale purification. Scale purification began with the computation of Cronbach's alpha to examine the item-to-total correlation (Ryu and Jang, 2008). Since one of the major uses of factor analysis is to support scale development because it provides information regarding its dimensionality (Worthington and Whittaker, 2006), exploratory and confirmatory factor analyses were used to purify scales and confirm the dimensionality of the definitive latent variables (Fabrigar and Wegener, 2012). The exploratory factor analysis (EFA) was performed using the Statistical Package for Social Sciences (SPSS) 25.0 in order to reduce the items to a smaller set of variables. Finally, to confirm the structure of QUICKSERV, the Stata 15.0 statistical package was used to perform first-order and secondorder confirmatory factor analyses (CFA). The details of these analyses are explained in the following section. 
BFJ 123,13

248

\section{Findings}

\subsection{Exploratory factor analysis}

Before applying data reduction and dimensionality, the scale's reliability was explored by calculating Cronbach's alpha. At this stage, two indicators (1 and 17) were dropped because their corrected item-to-total correlation was below 0.50. EFA was then conducted on the other 19 items, using the principal component analysis with Varimax rotation and Kaiser normalization. As a result, two new items were dropped ( 8 and 10), since they did not comply with the criterion of factor loading above 0.50 (Hair et al., 2019). Likewise, three problematic cases of cross-loading were identified and after computing the ratio of variances, another three variables were dismissed (6, 7 and 9). Thus, after a second EFA, the scale was finally reduced to 14 items. EFA revealed that three factors emerged with eigenvalues greater than 1.0. These three factors accounted for $71.38 \%$ of the overall variance (see Table 3). The communalities of all items were acceptable since they ranged from 0.59 to 0.86 . Cronbach's alpha values of the three dimensions ranged from 0.81 to 0.93 , exceeding the recommended threshold of 0.70 (Hair et al., 2019). The Kaiser-Meyer-Olkin value of 0.932 and a significant Chi-square value for Bartlett's test of sphericity $\left(\chi^{2}=4172.076, p<0.000\right)$ indicate that factor analysis is appropriate for the data.

The EFA analysis presented a scale composed of three factors. The first is called Physical Environment Perception (PEP), as already considered in previous research (Ryu and Han, 2010; Ryu et al., 2012; Ryu and Lee, 2017), and in our case, after the second EFA this factor comprises four items, whose factor loadings range between 0.64 and 0.81 , explaining $19.70 \%$ of the overall variance. The second factor, named Interaction Quality Perception (IQP), focuses on the interaction time and staff behavior during the service encounter. It is composed of six items that represent intangible characteristics. This dimension represents the most significant factor because it explains practically $30 \%$ of the total variance. This result would be supported by the leading role of the service encounter in this kind of restaurant and the importance of the quickness of service for QSR customers (Massimino and Lawrence, 2019; Lu and Chi, 2018). In fact, it is also noted that the means of the two indicators related to speed of service ("Proper service time" and "Enough staff to attend to consumers") have higher

\begin{tabular}{lcccc}
\hline & & Eigen- & & \\
QUICKSERV dimensions (Reliability alpha) & Factor loading & $\begin{array}{c}\text { values } \\
\text { Variance explained }\end{array}$ & Means \\
\hline $\begin{array}{l}\text { Physical environment perception (0.809) } \\
\text { Attractive place and pleasant atmosphere }\end{array}$ & 0.678 & 2.759 & \multirow{2}{*}{19.704} & 5.25 \\
Well-painted walls and proper lighting & 0.782 & & & 4.80 \\
Attractive exterior signs and appearance & 0.807 & & & 5.39 \\
Comfortable indoor temperature & 0.642 & & & 5.31 \\
Interaction quality perception (0.928) & & 4.196 & 29.969 & 5.48 \\
Proper service time (order preparation) & 0.744 & & & 6.03 \\
Enough staff to attend to consumers & 0.784 & & & 5.98 \\
Experienced and well-trained employees & 0.790 & & & 5.93 \\
Staff have a pleasant attitude & 0.775 & & & 5.89 \\
Staff have a clean and well-groomed look & 0.756 & & & 5.88 \\
Staff are dynamic and friendly & 0.779 & 3.039 & & 5.91 \\
Food quality perception (0.885) & & & & 5.60 \\
Fresh and properly cooked food & 0.812 & & & 5.52 \\
Delicious and tasty food & 0.856 & & & 5.70 \\
Sufficient variety of choices on the menu & 0.749 & & & 5.66 \\
Practical and hygienic food packaging & 0.656 & & \\
Total variance & $71.38 \%$ & & & \\
\hline
\end{tabular}

Table 3.

Results of EFA 
means than the other indicators, highlighting how, in our case, quickness of service was highly rated. Finally, the Food Quality Perception ( $F Q P$ ) factor involves not only items to evaluate the characteristics of food, but also includes two items related to other food aspects, namely "sufficient variety of choices on the menu" and "practical and hygienic food packaging." These last two issues are considered of great importance in the context of the QSR industry (Ottenbacher and Harrington, 2009). This factor accounts for $21.71 \%$ of the overall variance, a result that clearly reflects its relevance.

QUICKSERV:a service quality assessment tool

\subsection{Confirmatory factor analysis}

In order to verify the previously identified factor structure, a CFA using the maximum likelihood method of estimation was performed. Although the assumption of multivariate normality in social and behavioral sciences is questionable, the factorial analysis literature recognizes the maximum likelihood estimation as robust against nonnormality (Jöreskog et al., 2016). First, we have developed a first-order CFA, examining the pattern and measures of factor correlations in this first-order solution. We then fitted the second-order factor model on the grounds of theoretical and empirical evidence. The results show that CFA of the first-order model fits the data reasonably well, according to goodness-of-fit indices: Chi-square $\left(\chi^{2}\right)=340,87, p$-value $=000$; degree of freedom $(\mathrm{df})=74$, root mean square error of approximation (RMSEA) $=0.092$; comparative fit index $(\mathrm{CFI})=0.94$; goodness of fit index $(\mathrm{GFI})=0.88$; standardized root mean square residual $(\mathrm{SRMR})=0.047$ and Tucker-Lewis index $(\mathrm{TLI})=0.92$, although there is certainly room for their further improvement.

Since the goodness-of-fit indices only provide a general description of the ability to reproduce the observed relationships, more information to pinpoint reasons why a model fits insufficiently is needed (Brown, 2015). For this purpose, following Worthington and Whittaker (2006), we analyzed the residuals and modification indices to identify the areas of misfit in the CFA solution and to perform the most appropriate changes provided they are justified by theory (Hair et al., 2019). After identifying certain groups of highly correlated items and analyzing the modification indices, the identification of a few residual error correlations in the model was recommendable. In this regard, Silvia and MacCallum (1988), cited by Brown (2015), found that restricting modification indices that were theoretically justified improved the post hoc revisions of a fitted model. Thus, based on the evidence that items 11, 12 and 13 of the IQP construct are highly correlated, because they respond to questions and aspects related to the perception of interaction time, they have been included in the second-order model (Figure 1) in a post hoc manner.

As set out in the research objectives, our approach is based on a second-order structure, because such a model is more parsimonious than a first-order one (Hair et al., 2019). Therefore, after the post hoc modification, a new CFA of this second-order model was performed, thereby improving all goodness-of-fit indices (see Table 4). It is important to highlight that the consideration of residual error correlations in the model has not involved relevant changes to the factor loading values, either in reliability or in validity measurements of all constructs.

In certain cases, the modification indices revealed aspects that were not previously foreseen in the initial model. Only when they are theoretically justified is it acceptable for them to be used to improve the fit (Brown, 2015). In our case, it was noted that the IQP factor involves six variables that could be treated separately in two different groups: one group would comprise items 11, 12 and 13, which bundles the perception of the specific interaction time; and another group that would be constituted by items 14, 15 and 16 is related to perceptions of the staff that participate in the service interaction. Regarding this last group, Ryu and Jang (2008) also identified service staff as an individual factor in the DINESCAPE scale. 
BFJ

123,13

250

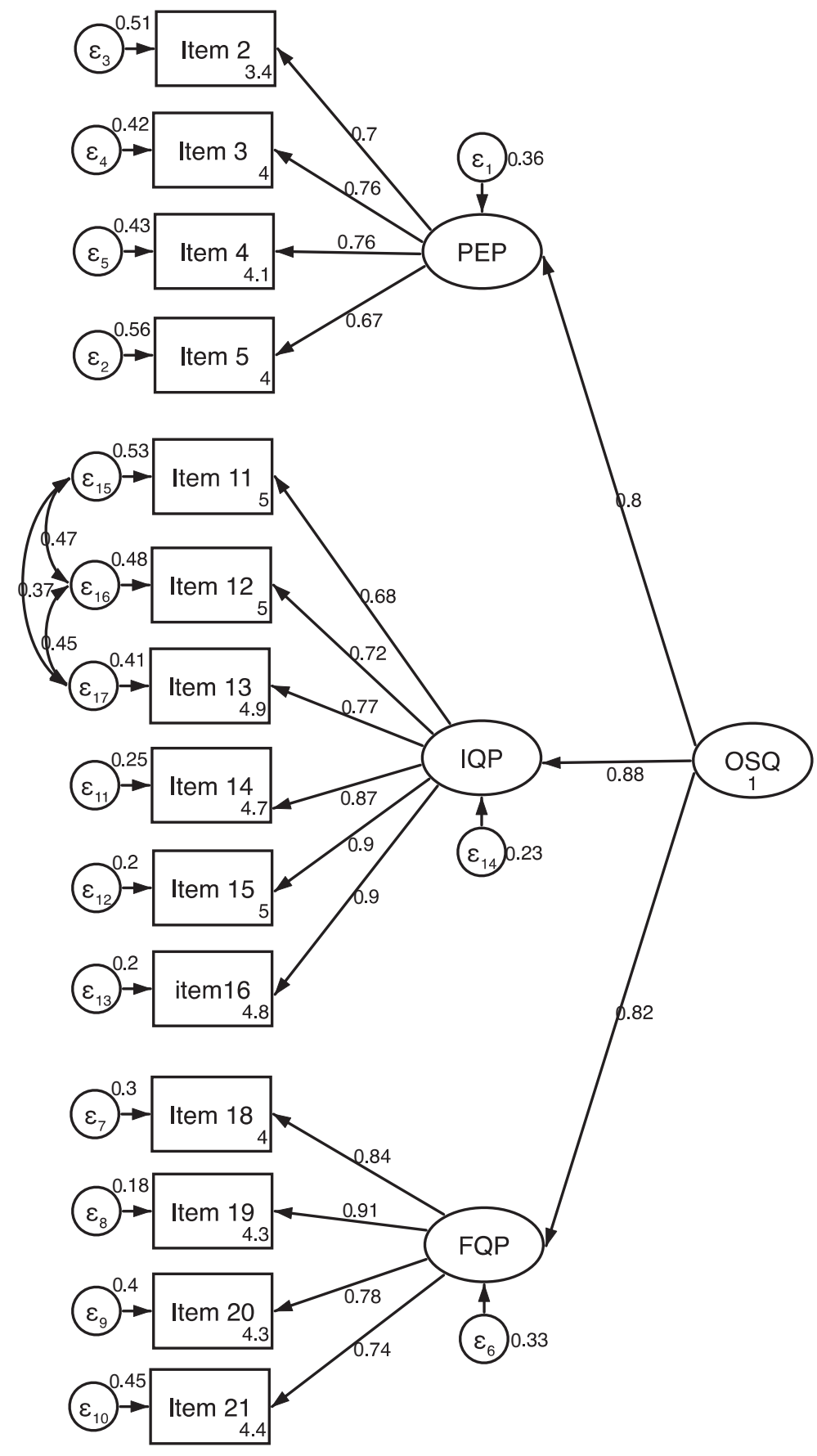

Figure 1.

Second-order three-

factor model 


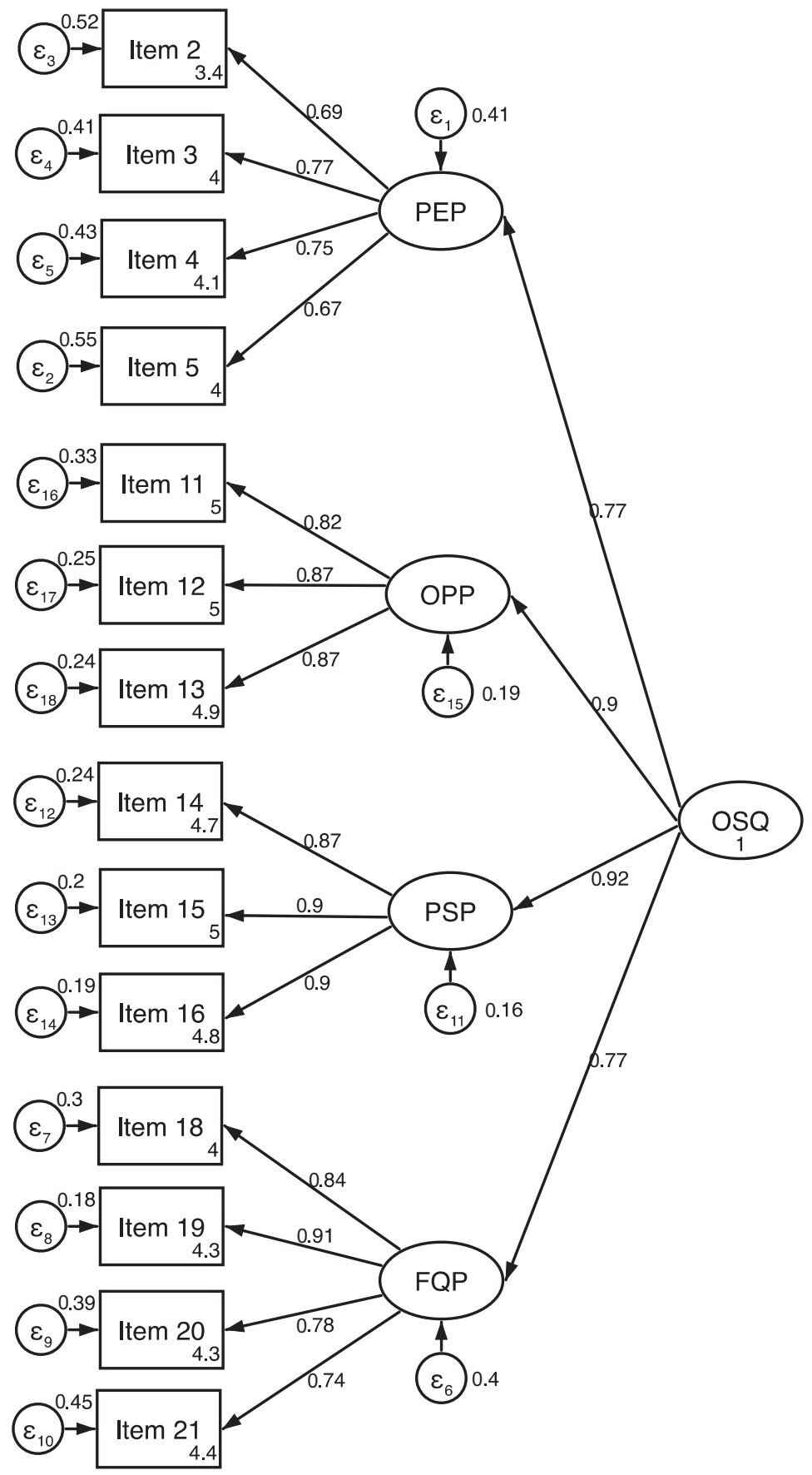

QUICKSERV:a service quality assessment tool

251

Figure 2. Second-order fourfactor model 


\begin{tabular}{llccc} 
BFJ & S23,13 & $\begin{array}{c}\text { Suggested } \\
\text { threshold }\end{array}$ & $\begin{array}{c}\text { Three-factor second-order } \\
\text { model* }\end{array}$ & $\begin{array}{c}\text { Four-factor second-order } \\
\text { model }\end{array}$ \\
\cline { 2 - 5 } & Chitistic & $p \geq 0.05$ & $176.31(0.000)$ & $173.14(0.000)$ \\
& CFI & $\geq 0.95$ & 0.98 & 0.98 \\
& TLI & $\geq 0.95$ & 0.97 & 0.97 \\
$\mathbf{2 5 2}$ & GFI & $\geq 0.90$ & 0.94 & 0.95 \\
\hline & RMSEA & $\leq 0.08$ & 0.059 & 0.046 \\
& RMSEA 90\%, lower- & $\leq 0.05$ & 0.048 & 0.067 \\
baund & & & 0.156 \\
Table 4. & RMSEA 90\%, upper- & $\leq 0.10$ & 0.070 & 0.045 \\
comparison & bound & $p \geq 0.05$ & & \\
\hline
\end{tabular}

Based on the previous identification of these two groups of variables within a unique construct, we decided to split the IQP construct into two individual constructs that were named Operations Performance Perception (OPP) and Personnel Service Perception (PSP). This adapted structure constitutes a new second-order model (Figure 2) that has been tested by performing a new CFA with better goodness-of-fit indices (see Table 4). These indices provided evidence that these four new factors in the model perform a better fit, and based on Gerbing and Anderson's (1984) recommendations, this latter representation is preferable, since it does not require the identification of correlated errors. In addition, this finding supports the need to reappraise the Interaction Quality dimension in the QSR context, since it groups indicators that represent two different aspects of service quality, one associated with speedy service and other specifically related to the appearance and behavior of personnel.

Table 4 displays the goodness-of-fit indices of the two second-order models. The good accuracy of this fit is supported by CFI and TLI, which surpass the recommended criterion of 0.95, while GFI exceeds the recommended value of 0.90 (Hair et al., 2019) and the RMSEA values are below the suggested threshold of 0.08 (Jöreskog et al., 2016). Finally, the SRMR values are below the suggested threshold of 0.08 (Brown, 2015).

Finally, after analyzing all goodness-of-fit indices and based on conceptual and empirical support, we decided to choose the four-factor second-order model as the definitive structure of QUICKSERV.

\subsection{Measurement reliability and validity}

As shown in Table 5, Cronbach's alpha estimations of the four constructs are correct since they are in the range of $0.81-0.92$, exceeding the cutoff point of 0.70 and indicating the internal consistency of the measured items (Hair et al., 2019). The reliability of each dimension was also assessed by calculating composite reliability (CR) and average variance extracted (AVE). CR of all factors ranges from 0.81 to 0.92 , exceeding the cutoff point of 0.70 but not above 0.95 (Hair et al., 2019), ensuring adequate internal consistency for each construct. AVE values range from 0.52 to 0.79 , exceeding the recommended value of 0.50 (Fornell and Larcker, 1981) and hence supporting convergent validity. AVE values also support discriminant validity, because the AVE of each of the constructs exceeds the highest square of the estimated correlations among the associated constructs (Fornell and Larcker, 1981). In this regard, the confidence interval around the correlations between factors did not include the value of 1 (Anderson and Gerbing, 1988). Moreover, all standardized factor loadings range from 0.67 to 0.9 , meeting the minimum criterion of 0.50 (Hair et al., 2019), and 12 items exceed the ideal value of 0.70 . They are all statistically significant, which also supports convergent validity. 


\begin{tabular}{|c|c|c|c|c|}
\hline QUICKSERV dimensions (Cronbach' alpha) & Standardized factor loadings & $\mathrm{CR}$ & $\mathrm{AVE}$ & QUICKSERV:a \\
\hline Physical environment perception (0.809) & & 0.813 & 0.521 & assessmer \\
\hline Attractive place and pleasant atmosphere & 0.694 & & & \\
\hline Well-painted walls and proper lighting & 0.766 & & & \\
\hline Attractive exterior signs and appearance & 0.755 & & & \\
\hline Comfortable indoor temperature & 0.668 & & & \\
\hline Operations performance perception (0.889) & & 0.889 & 0.728 & 25 \\
\hline Proper service time (order preparation) & 0.820 & & & \\
\hline Enough staff to attend to consumers & 0.867 & & & \\
\hline Experienced and well-trained employees & 0.871 & & & \\
\hline Personnel service perception (0.919) & & 0.919 & 0.792 & \\
\hline Staff have a pleasant attitude & 0.871 & & & \\
\hline Staff have a clean and well-groomed look & 0.897 & & & \\
\hline Staff are dynamic and friendly & 0.901 & & & \\
\hline Food quality perception (0.885) & & 0.889 & 0.669 & \\
\hline Fresh and properly cooked food & 0.835 & & & Table \\
\hline Delicious and tasty food & 0.906 & & & Measureme \\
\hline Sufficient variety of choices on the menu & 0.778 & & & properties (fou \\
\hline Practical and hygienic food packaging & 0.743 & & & factor model) \\
\hline
\end{tabular}

\section{Discussion of the findings}

According to our findings, customers placed emphasis on items that are directly related to service interaction, which appear in the operations performance and personnel service dimensions. The former dimension is directly related to interaction time and the latter evaluates staff-customer interaction. This finding is supported by the importance of utilitarian value and the required speed of service in this type of restaurant (Nejati and Moghaddam, 2013; Lu and Chi, 2018; Izquierdo-Yusta et al., 2019) and demonstrates that QSR costumers primarily value a speedy service and pleasant treatment. In this regard, Massimino and Lawrence (2019) recommended measurement and monitoring of the speed of service in QSRs, in order to assure operational efficiency and franchisee compliance. Bode et al. (2011) stated that interactions between personnel and consumers during the service encounter have a high effect on service quality perception, and in the same vein, Swimberghe and Wooldridge (2014) expressed that customers who have positive perceptions of the employees with whom they interact will be more likely to identify themselves with firms. While previous studies have employed single items to capture this dimension (GallarzaGranizo et al., 2020; Slack et al., 2020), the current study proposes three ("Proper service time"; "Enough staff to attend to consumers"; "Experienced and well-trained employees"). These three items are more appropriate for capturing the interaction interface, since quick service not only depends on employee ability, but also on the performance of operational processes and the number of employees assigned to a shift. All of this provides valuable insights to improve restaurant management.

The study's results suggest that another highly valued dimension is food quality, which is considered one of the main service quality factors because of its relevant influence on customer satisfaction in the restaurant industry (Namkung and Jang, 2007; Ha et al., 2010; Qin et al., 2010). In this regard, Bujisic et al. (2014) found that food quality is directly related to customer intention in both upscale and QSRs. In the same vein, Qin and Prybutok (2008) and Ryu and Han (2010), using the same conceptual framework found a direct and significant relationship between food quality and customer satisfaction in fast-food and quick-casual restaurants, respectively. Likewise, food quality is also positively related to perceived value, as identified by Oh et al. (2019) in their study of the Coffee Shop segment of the US and Korean 
BFJ

123,13

markets. All in all, food quality is still considered to be a critical dimension to assess service quality in the context of QSR.

Finally, perception of the physical environment is the fourth dimension of our service quality model. In our case, items in this dimension received the lowest mean scores from customers of a QSR in Barcelona, in line with Ryu and Jang's (2008) finding that the physical environment is less important in QSRs than in upscale ones. Richardson et al. (2019) did not identify a statistically significant relationship between ambience and customer satisfaction in QSRs either. However, according to Tsai et al. (2007), store appearance is an important factor for the analysis of service quality in fast food chains, and our study supports this claim.

An additional relevant finding that will require further empirical testing is related to the four-factor structure. QUICKSERV draws on the three-element approach by Rust and Oliver (1994) and on subsequent studies that adopted it, such as Brady and Cronin (2001), and Wu and Mohi (2015). These studies used different denominations to the originals: outcome quality, interaction quality and physical environment quality. However, our results highlighted that splitting the interaction quality dimension into two different factors, personnel service and operations performance, improves the goodness of fit of the structure developed to assess the service quality perception in QSR. This new structure clearly identifies four relevant and independent aspects of service quality with regard to QSR, leading us to consider it more accurate and convenient to evaluate interaction quality on the basis of two dimensions: the first focused on performance and speed of service; and the second on staff behavior during interaction with customers.

\section{Conclusions}

Although the importance of service quality has been extensively studied across many pure service and product-service contexts, previous research lacks specificity in the measurement of this construct in some particular contexts. The purpose of this study was to develop a measurement scale to assess service quality in one of those contexts: QSRs. As suggested by (Boshoff, 1999), what does not get measured does not get properly managed. Therefore, we believe that the lack of studies that provide a practical and comprehensive instrument for measuring the distinct elements of perceived service quality in QSR restaurants may restrict, on the one hand, academic understanding of how service quality affects consumer behaviors and, on the other hand, managerial ability and knowledge to efficiently manage their restaurants.

It is clear that the scales used to assess different aspects of service quality (e.g. SERVQUAL, DINESERV, TANGSERV and DINESCAPE) present several limitations for the comprehensive measurement of service quality in the QSR industry. Moreover, although the hierarchical scale proposed by Wu and Mohi (2015) was specifically developed for QSR, its complex and extensive structure hampers its practical implementation. In order to overcome these drawbacks and provide managerial solutions for this industry, this study presents QUICKSERV, a novel scale that comprises 14 items in four factors (perceptions of physical environment, operations performance, personnel service and food quality). These factors are highly correlated and yield a second-order factor structure that allows capture of both the underlying commonality among dimensions and the extent to which the dimensions represent overall service quality. In addition, given that the customers' perspective is an essential element of service quality management (Qin et al., 2010), QUICKSERV has been developed for implementation as a practical tool in QSR management systems, in order to provide relevant information that assures compliance with service quality standards. For that purpose, this scale has been validated by rigorous methodological criteria and is theoretically supported by previous studies (Brady and Cronin, 2001; Qin and Prybutok, 2008; Ryu and Jang, 2008; Ryu et al., 2012; Wu and Mohi, 2015; Oh et al., 2019) making it a useful instrument for future research in the marketing and hospitality fields. 
In addition, after validating the QUICKSERV scale, we conclude that QSR chains need to focus on having trained and satisfied employees, as well as streamlined operative processes, in order to ensure two key aspects of service quality (good personnel service and high operations performance). Furthermore, they should serve delicious, tasty food, using practical and hygienic packaging, in order to ensure a positive perception of the food quality factor. Finally, QSR restaurants should also focus their attention on the physical environment, building restaurants with a pleasant indoor atmosphere and appealing exterior designs. Therefore, our findings highlight the importance of separately assessing the perceptions of performance and speed service, as well as employee behavior, thus capturing more accurate information to improve restaurant operations management. Performance and speed of service not only depend on the good employee behavior, but also require good staff scheduling to deal with a large volume of customers per shift, good induction and training programs, as well as good and properly functioning equipment. Hence, the perception of operational performance is an important dimension of the QUICKSERV scale, and a differential factor with regard to all previous scales that failed to identify this relevant aspect of the interaction quality dimension. Perceptions of personnel service and operational performance are therefore two dimensions of QUICKSERV that are worthy of consideration in future research analyzing service quality in similar settings.

Theoretical and practical contributions derive from the above findings. First, this study provides empirical support for Rust and Oliver's (1994) conceptualization of service quality. Another academic contribution is reflected in the identification of two specific dimensions (perceptions of operational performance and personnel service) that were initially part of a single dimension (perception of interaction quality). This finding introduces a novel fourfactor model, providing a better framework to measure service quality perceptions at the service encounter, so future research could use this new second-order construct. Second, QUICKSERV also presents managerial contributions. One is related to its short and comprehensive questionnaire, which is easier to apply to real QSR settings, since customers spend little time in this type of restaurant. This practical approach makes QUICKSERV a good instrument to measure and control compliance with quality standards in the QSR context. Another contribution is linked to franchise management, because QSR franchise chains work on the basis of protocols and standardized operations, to which QUICKSERV contributes by serving as a noncoercive control tool for franchisors and restaurant operators, considering that noncoercive mechanisms have a major positive impact on the relationship between franchisor and franchisees (Doherty, 2007). This involves not penalizing franchisees but helping them to identify opportunities for continuous improvement. Finally, since QUICKSERV can afford precise information gathered from the customers of each business unit, it can be used to monitor a unit's own evolution, by comparing its results with previous scores, as well as the scores of other business units. In addition, headquarters could have access to real-time global data by implementing QUICKSERV on its restaurant management systems.

Besides academic and managerial implications, this study also presents some limitations and new avenues for future research. First, its compact factor structure comprises a limited number of specific items for assessing service quality in QSR, such as "proper service time" and "practical food packaging," so its use would not be recommended in other types of restaurants that require collection of more extensive and detailed information. A second limitation is related to data, since it was collected from customers of a particular franchised restaurant. QUICKSERV needs further testing not only in other restaurants in the same chain, but also in other global QSR chains. Further testing in different countries would also be needed in order to analyze the influence of cultural factors on the service quality perception at QSR chains that operate internationally. Third, since the survey is so short and hence easier to apply at the service encounter, the influence of service quality on actual purchasing

QUICKSERV:a service quality assessment tool

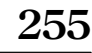


BFJ 123,13

behavior could feasibly be assessed. Finally, another future line is related to the implementation of QUICKSERV as a noncoercive control tool in QSR franchise chains, in order to analyze the usefulness of the continuous measurement of service quality in international franchise management.

\section{References}

Anderson, J.C. and Gerbing, D.W. (1988), "Structural equation modeling in practice: a review and recommended two-step approach”, Psychological Bulletin, Vol. 103 No. 3, pp. 411-423.

Angelova, B. and Zekiri, J. (2011), "Measuring customer satisfaction with service quality using American customer satisfaction model (ACSI model)", International Journal of Academic Research in Business and Social Sciences, Vol. 1 No. 3, pp. 25-48.

Antun, J.M., Frash, R.E., Costen, W. and Runyan, R.C. (2010), “Accurately assessing expectations most important to restaurant patrons: the creation of the dinex scale", Journal of Foodservice Business Research, Vol. 13 No. 4, pp. 360-379.

Bode, C., Lindemann, E. and Wagner, S. (2011), "Driving trucks and driving sales? the impact of delivery personnel on customer purchase behavior", Journal of Business Logistics, Vol. 32 No. 1, pp. 99-114.

Boshoff, C. (1999), "Recovsat: an instrument to measure satisfaction with transaction-specific service recovery", Journal of Service Research, Vol. 1 No. 3, pp. 236-249.

Brady, M.K. and Cronin, J.J.J. (2001), "Some new thoughts on conceptualizing perceived service quality: a hierarchical approach", Journal of Marketing, Vol. 65, pp. 34-39.

Brown, T.A. (2015), Confirmatory Factor Analysis for Applied Research, 2nd, The Guilford Press, New York, NY.

Bufquin, D., DiPietro, R. and Partlow, C. (2017), "The influence of the DinEX service quality dimensions on casual-dining restaurant customers' satisfaction and behavioral intentions", Journal of Foodservice Business Research, Routledge, Vol. 20 No. 5, pp. 542-556.

Bujisic, M., Hutchinson, J. and Parsa, H.G. (2014), "The effects of restaurant-related attributes on customer behavioral intentions", International Journal of Contemporary Hospitality Management, Vol. 26 No. 8, pp. 1270-1291.

Calabrese, A. and Scoglio, F. (2012), "Reframing the past: a new approach in service quality assessment”, Total Quality Management and Business Excellence, Vol. 23 No. 11, pp. 1329-1343.

Cao, Y. and Kim, K. (2015), "How do customers perceive service quality in differently structured fast food restaurants?”, Journal of Hospitality Marketing and Management, Vol. 24 No. 1, pp. 99-117.

Churchill, G.A. (1979), "A paradigm for developing better measures of marketing constructs”, Journal of Marketing Research, Vol. 16 No. 1, pp. 64-73.

Cronin, J.J. and Taylor, S.A. (1992), "Measuring service quality: a reexamination and extension", Journal of Marketing, Vol. 56 No. 3, pp. 55-68.

Cronin, J.J.J., Brady, M.K. and Hult, G.T.M. (2000), "Assessing the effects of quality, value, and customer satisfaction on consu ... discovery service for air force institute of technology", Journal of Retailing, Vol. 76 No. 2, pp. 193-218.

DiPietro, R. (2017), "Restaurant and foodservice research: a critical reflection behind and an optimistic look ahead”, International Journal of Contemporary Hospitality Management, Vol. 29 No. 4, pp. 1203-1234.

DiPietro, R.B., Gregory, S. and Jackson, A. (2013), "Going green in quick-service restaurants: customer perceptions and intentions", International Journal of Hospitality and Tourism Administration, Vol. 14 No. 2, pp. 139-156.

Doherty, A.M. (2007), "Support mechanisms in international retail franchise networks", International Journal of Retail and Distribution Management, Vol. 35 No. 10, pp. 781-802. 
Djofack, S. and Camacho, M.A.R. (2017), "Implementation of ISO 9001 in the Spanish tourism industry", International Journal of Quality and Reliability Management, Vol. 34 No. 1, pp. 18-37.

Fabrigar, L.R. and Wegener, D.T. (2012), Exploratory Factor Analysis, 1st., Oxford University Press, New York, NY.

Fornell, C. and Larcker, D.F. (1981), "Evaluating structural equation models with unobservable

QUICKSERV:a service quality assessment tool variables and measurement error", Journal of Marketing Research, Vol. 1, pp. 39-50.

Gallarza-Granizo, M.G., Ruiz-Molina, M.E. and Schlosser, C. (2020), "Customer value in quick-service restaurants: a cross-cultural study", International Journal of Hospitality Management, Elsevier 2019, Vol. 85 February, p. 102351.

Gerbing, D.W. and Anderson, J.C. (1984), "On the meaning of within-factor correlated measurement errors", Journal of Consumer Research, Vol. 11 No. 1, p. 572.

Gummesson, E. (2014), "Productivity, quality and relationship marketing in service operations: a revisit in a new service paradigm", International Journal of Contemporary Hospitality Management, Vol. 26 No. 5, pp. 656-662.

Ha, J., Jang, S.C. and Shawn (2010), "Effects of service quality and food quality: the moderating role of atmospherics in an ethnic restaurant segment", International Journal of Hospitality Management, Elsevier, Vol. 29 No. 3, pp. 520-529.

Hair, JJJ.F., Black, W.C., Babin, B.J. and Anderson, R.E. (2019), Multivariate Data Analysis, 8th ed., Cengage Learning EMEA, Andover.

Hinkin, T.R. (1995), "A review of scale development practices in the study of organizations", Journal of Management, Vol. 21 No. 5, pp. 967-988.

Hoover, V.L., Ketchen, D.J. Jr and Combs, J.G. (2003), "Why restaurant firms franchise”, Cornell Hotel and Restaurant Administration Quarterly, Vol. 44 No. 1, pp. 9-16.

Izquierdo-Yusta, A., Gómez-Cantó, C.M., Pelegrin-Borondo, J. and Martínez-Ruiz, M.P. (2019), "Consumers' behaviour in fast-food restaurants: a food value perspective from Spain", British Food Journal, Vol. 121 No. 2, pp. 386-399.

Jöreskog, K.G., Olsson, U.H. and Wallentin, F.Y. (2016), Multivariate Analysis with LISREL, Springer, Basel.

Knutson, B., Stevens, P., Wullaert, C., Patton, M. and Yokoyama, F. (1990), "Lodgserv: a service quality index for the lodging industry", Hospitality Research Journal, Vol. 14 No. 2, pp. 277-284.

Krueger, A.B. (2013), "Ownership, agency, and Wages : an examination of franchising in the fast food industry", The Quarterly Journal of Economics, Vol. 106 No. 1, pp. 75-101.

Kukanja, M. and Planinc, T. (2020), "Toward cost-effective service excellence: exploring the relationship between managers' perceptions of quality and the operational efficiency and profitability of restaurants", Quality Management Journal, Taylor \& Francis, No. 2, Vol. 27, pp. 95-105.

Lock, S. (2019), "Consumer spending in the quick service restaurant (QSR) sector in the United States from 2004 to 2018 (in billion U.S. dollars)", Statista (n.d.), Vol. 21 February, available at: www. statista.com/statistics/259148/consumer-spending-us-qsr-sector/ (accessed 29 March 2019).

Lu, L. and Chi, C.G. (2018), "An examination of the perceived value of organic dining”, International Journal of Contemporary Hospitality Management, Vol. 30 No. 8, pp. 2826-2844.

Marković, S., Šegarić, K. and Raspor, S. (2010), 'Does restaurant performance meet customers' expectations? An assessment of restaurant service quality using a modified DINESERV approach", Tourism and Hospitality Management, Vol. 16 No. 2, pp. 181-195.

Massimino, B. and Lawrence, B. (2019), "Supersize me? Franchisee size and voluntary compliance with corporate brand-building initiatives", Journal of Operations Management, Vol. 65 No. 7, pp. 659-684.

Mathe-Soulek, K., Slevitch, L. and Dallinger, I. (2015), "Applying mixed methods to identify what drives quick service restaurant's customer satisfaction at the unit-level", International Journal of Hospitality Management, Elsevier, Vol. 50, pp. 46-54. 
BFJ 123,13

Nam, J., Ekinci, Y. and Whyatt, G. (2011), "Brand equity, brand loyalty and consumer satisfaction", Annals of Tourism Research, Elsevier, Vol. 38 No. 3, pp. 1009-1030.

Namkung, Y. and Jang, S.C. (2007), "Does food quality really matter in restaurants? Its impact on customer satisfaction and behavioral intentions", Journal of Hospitality and Tourism Research, Vol. 31 No. 3, pp. 387-409.

Namkung, Y. and Jang, S.C. (2008), "Are highly satisfied restaurant customers really different? A quality perception perspective", International Journal of Contemporary Hospitality Management, Vol. 20 No. 2, pp. 142-155.

Nejati, M. and Moghaddam, P.P. (2013), "The effect of hedonic and utilitarian values on satisfaction and behavioural intentions for dining in fast-casual restaurants in Iran", British Food Journal, Vol. 115 No. 11, pp. 1583-1596.

Nguyen, Q., Nisar, T.M., Knox, D. and Prabhakar, G.P. (2018), "Understanding customer satisfaction in the UK quick service restaurant industry: the influence of the tangible attributes of perceived service quality", British Food Journal, Vol. 120 No. 6, pp. 1207-1222.

Oh, D., Yoo, M., Myongjee and Lee, Y. (2019), "A holistic view of the service experience at coffee franchises: a cross-cultural study", International Journal of Hospitality Management, Vol. 82 November, pp. 68-81.

Ottenbacher, M.C. and Harrington, R.J. (2009), "The product innovation process of quick-service restaurant chains", International Journal of Contemporary Hospitality Management, Vol. 21 No. 5, pp. 523-541.

Parasuraman, A., Zeithaml, V.A. and Berry, L.L. (1988), "SERVQUAL: a multiple-item scale for measuring consumer perceptions of service quality", Journal of Retailing, Vol. 64 No. 1, pp. $12-40$.

Paul, M., Hennig-Thurau, T., Gremler, D.D., Gwinner, K.P. and Wiertz, C. (2009), "Toward a theory of repeat purchase drivers for consumer services", Journal of the Academy of Marketing Science, Vol. 37 No. 2, pp. 215-237.

Qin, H. and Prybutok, V.R. (2008), "Determinants of customer-perceived service quality in fast-food restaurants and their relationship to customer satisfaction and behavioral intentions", Quality Management Journal, Vol. 15 No. 2, pp. 35-50.

Qin, H., Prybutok, V.R. and Zhao, Q. (2010), "Perceived service quality in fast-food restaurants: empirical evidence from China", International Journal of Quality and Reliability Management, Vol. 27 No. 4, pp. 424-437.

Raajpoot, N.A. (2002), “Tangserv”, Journal of Foodservice Business Research, Vol. 5 No. 2, pp. 109-127.

Reynolds, T.J. and Olson, J.C. (2001), "The means-end approach to understanding consumer decision making”, in Reynolds, T.J. and Olson, J.C. (Eds), Understanding Consumer Decision Making: The Means-End Approach to Marketing and Advertising Strategy, Lawrence Erlbaum Associates, Mahwah, NJ, pp. 3-20.

Richardson, S., Lefrid, M., Jahani, S., Munyon, M.D. and Rasoolimanesh, S.M. (2019), "Effect of dining experience on future intention in quick service restaurants", British Food Journal, Vol. 121 No. 11, pp. 2620-2636.

Rosado-Serrano, A., Paul, J. and Dikova, D. (2018), "International franchising: a literature review and research agenda", Journal of Business Research, Elsevier, Vol. 85 January, pp. 238-257.

Rust, R. and Oliver, R. (1994), "Service quality: insights and managerial implications from the frontier", in Rust, R.T. and Oliver, R.L. (Eds), Service Quality: New Directions in Theory and Practice, SAGE Publications, Thousand Oaks, CA, pp. 1-20.

Ryu, K. and Han, H. (2010), "Influence of the quality of food, service, and physical environment on customer satisfaction and behavioral intention in quick-casual restaurants: moderating role of perceived price", Journal of Hospitality and Tourism Research, Vol. 34 No. 3, pp. 310-329.

Ryu, K. and Jang, S. (2008), "DINESCAPE: a scale for customers' perception of dining environments", Journal of Foodservice Business Research, Vol. 11 No. 1, pp. 2-22. 
Ryu, K. and Lee, J.-S. (2017), "Examination of restaurant quality, relationship benefits, and customer reciprocity from the perspective of relationship marketing investments", Journal of Hospitality and Tourism Research, Vol. 41 No. 1, pp. 66-92.

Ryu, K., Lee, H.R. and Kim, W.G. (2012), "The influence of the quality of the physical environment, food, and service on restaurant image, customer perceived value, customer satisfaction, and behavioral intentions", International Journal of Contemporary Hospitality Management, Vol. 24 No. 2, pp. 200-223.

Silvia, E.S. and MacCallum, R.C. (1988), "Some factors affecting the success of specification searches in covariance structure modeling”, Multivariate Behavioral Research, Vol. 23 No. 3, pp. 297-326.

QUICKSERV:a service quality assessment tool

Slack, N.J., Singh, G., Ali, J., Lata, R., Mudaliar, K. and Swamy, Y. (2020), "Influence of fast-food restaurant service quality and its dimensions on customer perceived value, satisfaction and behavioural intentions", British Food Journal, Vol. 123 No. 4, pp. 1324-1344.

Stevens, P., Knutson, B. and Patton, M. (1995), "DINESERV: a tool for measuring service quality in restaurants", The Cornell Hotel and Restaurant Administration Quarterly, Vol. 36 No. 2, pp. 56-60.

Swimberghe, K.R. and Wooldridge, B.R. (2014), "Drivers of customer relationships in quick-service restaurants: the role of corporate social responsibility", Cornell Hospitality Quarterly, Vol. 55 No. 4, pp. 354-364.

Tsai, M.C., Shih, K.-H. and Chen, J.C.H. (2007), "A comparison of the service quality of fast food chain franchises", International Journal of Services and Standards, Vol. 3 No. 2, pp. 222-238.

Worthington, R.L. and Whittaker, T.A. (2006), "Scale development research: a content analysis and recommendations for best practices", The Counseling Psychologist, Vol. 34 No. 6, pp. 806-838.

Wu, H.C. and Mohi, Z. (2015), "Assessment of service quality in the fast-food restaurant”, Journal of Foodservice Business Research, Vol. 18 No. 4, pp. 358-388.

\begin{abstract}
About the authors
Mario Mendocilla holds a professional master's degree in Busines Research and actually is a $\mathrm{PhD}$ student at University of Barcelona. Before starting the $\mathrm{PhD}$ in Business, Mendocilla has been associate professor in Strategy at the Faculty of Business, Private University of the North at Peru. Prior to entering academia, he served for 10 years as Business Unit Manager and Director of Operations in different quick-service restaurant firms in Spain. Mario Mendocilla is the corresponding author and can be contacted at:mmendome13@alumnes.ub.edu

Paloma Miravitlles is associate professor in International Business and Strategy at the Department of Business, University of Barcelona. Dr. Miravitlles is currently member of the Business and Management research group and has been the Director of the MSc in Business Research at the University of Barcelona for more than 6 years. She has participated in several competitive research projects and published several articles in journals such as Technological Forecasting and Social Change, International Business Review or Management Decision, among others. Her research interests are framed within the international Business field and particularly, focuses on multinationals, foreign subsidiaries and internationalization of innovation.

Jorge Matute is associate professor in Marketing at IQS School of Management- Universitat Ramon Llull at Barcelona. He has a PhD in marketing and holds a professional master's degree in Corporate Communications and Advertising. He is a member of the research group Conhative recognized by the Government of Catalonia. His research interests focus on consumer behavior, sustainability and services marketing. He has published his research in journals such as the Journal of Business Ethics, Tourism Management, Corporate Social Responsibility and Environmental Management, Business Strategy and the Environment, Journal of Cleaner Production, Journal of Services Marketing or the Journal of Sustainable Tourism.
\end{abstract}

For instructions on how to order reprints of this article, please visit our website: www.emeraldgrouppublishing.com/licensing/reprints.htm Or contact us for further details: permissions@emeraldinsight.com 